Rationalizing Culture 



\section{Rationalizing Culture}

IRCAM, Boulez, and the Institutionalization of the Musical Avant-Garde

\section{Georgina Born}

UNIVERSITY OF CALIFORNIA PRESS

Berkeley · Los Angeles · London 
University of California Press

Berkeley and Los Angeles, California

University of California Press, Ltd.

London, England

(C) 1995 by

The Regents of the University of California

Born, Georgina, I955-

Rationalizing culture : IRCAM, Boulez, and the Institutionalization of the Musical Avant-Garde / Georgina Born.

p. $\mathrm{cm}$.

Includes bibliographical references and index.

ISBN 0-520-08 507-8 (alk. paper)

IRCAM (Research institute : France) 2. Avant-

garde (Music) - Social aspects. 3. Research

institutes - France - Anthropological aspects.

4. Boulez, Pierre, 1925--Influence. I. Title.

ML32.F82I745 1994

$306.4^{\prime} 84-$ dc2o

Printed in the United States of America

$\begin{array}{lllllllll}9 & 8 & 7 & 6 & 5 & 4 & 3 & 2 & \text { I }\end{array}$

The paper used in this publication meets the minimum requirements of American National Standard for Information Sciences - Permanence of Paper for Printed Library Materials, ANSI

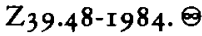


For my parents, Andrew, and Irma 

Modern art as an art of tyrannizing - A coarse and strongly defined logic of delineation; motifs simplified to the point of formulas; the formula tyrannizes. Within the delineations a wild multiplicity, an overwhelming mass, before which the senses become confused; brutality in color, material, desires.

Friedrich Nietzsche, The Will to Power (1887) 
